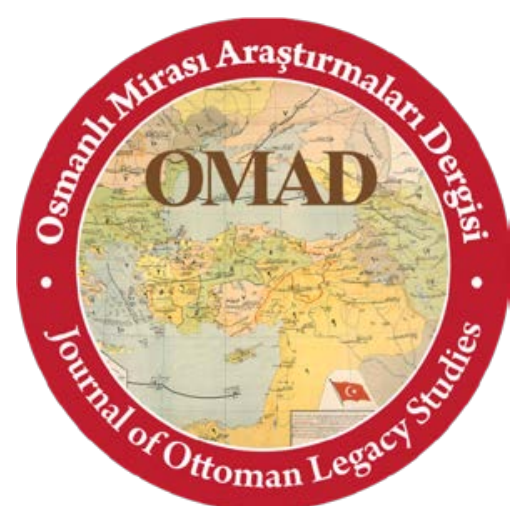

Osmanlı Mirası Araştırmaları Dergisi / Journal of Ottoman Legacy Studies

ISSN 2148-5704

www.osmanlimirasi.net

osmanlimirasi@gmail.com

Cilt 6, Sayı 14, Mart 2019 / Volume 6, Issue 14, March 2019

\title{
THE ROLE AND IMPORTANCE OF SAZ SEMAIS AND PEŞREVS IN CELLO TEACHING
}

Saz Semailerinin ve Peşrevlerin Viyolonsel Öğretimindeki Yeri ve Önemi

Makale Türü/Article Types : Araştırma Makalesi/Research Article

Geliş Tarihi/Received Date : 03.02.2019

Kabul Tarihi/Accepted Date : 05.03.2019

Sayfa/Pages : 97-114

DOI Numaras1/DOI Number : http://dx.doi.org/10.17822/omad.2019.113

\section{BURCU AVCI AKBEL}

(Dr. Öğr. Üyesi), Ankara Yıldırım Beyazıt Üniversitesi, Türk Musikisi Devlet Konservatuvarı, Türk Müziği Bölümü, Ankara / Türkiye, e-mail: burcuavci812002@yahoo.com, ORCID: https://orcid.org/0000-0002-3128-9295

\section{Atıf/Citation}

Avcı Akbel, Burcu, "The Role and Importance of Saz Semais and Peşrevs in Cello Teaching", Osmanlı Mirası Araştırmaları Dergisi, 6/14, 2019, s. 97-114.

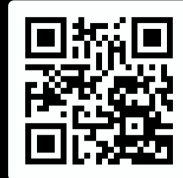

Scan me 

Osmanlı Mirası Araştırmaları Dergisi (OMAD), Cilt 6, Sayı 14, Mart 2019.

Journal of Ottoman Legacy Studies (JOLS), Volume 6, Issue 14, March 2019.

ISSN: $2148-5704$

\title{
THE ROLE AND IMPORTANCE OF SAZ SEMAIS AND PEŞREVS IN CELLO TEACHING
}

\author{
Saz Semailerinin ve Peşrevlerin Viyolonsel Öğretimindeki Yeri ve Önemi \\ BURCU AVCI AKBEL
}

\begin{abstract}
This study examined the role, importance and function of saz semais and peşrevs in cello teaching. It also examined the title and order of the pieces used in teaching, challenges experienced in the teaching of these pieces and suggestions for solutions. This study utilized phenomenological methodology. As a purposeful sampling method, maximum variation sampling method was employed in the selection of the study group ( $\mathrm{n}=10)$. Data were collected through interviews. The data in this study was analyzed by using the content analysis method. NVivo12, the qualitative data analysis software, was used for the analysis. In frame of this study, all the interviewees addressed the importance of saz semais and peşrevs, stating that they are essential in cello teaching. Some participants think that saz semais and peşrevs have benefits solely in teaching the maqams, while others argue their benefits in terms of control over the instrument and ear training, or in terms of enriching the repertoire, interpretation and teaching of nuances. Most of the participants reported that students had more difficulties in performing saz semais in comparison with peşrevs, while some other participants stated that the level of difficulty varied depending on the piece. It has been revealed that students have the most difficulties in providing the correct intonation, correct use of the positions and correct bow technique while performing saz semais and peşrevs.
\end{abstract}

Keywords: Turkish Music, Cello education, Cello teaching, Saz semai, Peşrev

Öz. Bu araştırmada saz semailerinin ve peşrevlerin viyolonsel öğretimindeki yeri, önemi, işlevi, hangi eserlerin hangi sıra ile öğretildiği, bu eserlerin öğretiminde yaşanan zorluklar ve çözüm önerileri hususları araştırılmıștır. Bu araștırma olgubilim deseni kullanılarak gerçekleștirilen nitel bir çalıșmadır. Araştırmada çalışma grubunun seçiminde, amaçlı örneklem yöntemlerinden maximum çeşitlilik örneklemesi kullanılmıştır $(\mathrm{n}=10)$. Verilerin toplanmasında görüşme tekniğinden yararlanılmış, elde edilen veriler içerik analizi yöntemi kullanılarak analiz edilmiştir. Verilerin analiz edilmesinde NVivo 12 nitel veri analizi programı kullanılmıştır. Bu araştırmada görüşme yapılan tüm katılımcılar saz semailerinin ve peşrevlerin önemine değinmiş, bu eserlerin öğretimde yararlı olduğunu belirtmişlerdir. Bazı katılımcılar saz semailerinin ve peşrevlerin sadece makam öğretimi hususunda yararlı olduğunu düşünürken, bazıları viyolonsel hâkimiyeti ve işitme eğitimi konularında; bazıları ise repertuvar geliştirme, yorumlama ve nüansların öğretimi açılarından yarar sağladığını düşünmektedir. Katılımcıların çoğu öğrencilerin saz semailerinde peşrevlere göre daha fazla zorlandıklarını belirtirken, bazıları ise eserden esere zorluk derecesinin değiştiğini ifade etmiştir. Öğrencilerin saz semailerini ve peşrevleri icra ederken en çok doğru entonasyonun sağlanması, pozisyonların doğru kullanımı ve doğru teknikle arşe kullanımı konularında zorlandıkları ortaya çıkmıştır.

Anahtar Kelimeler: Türk Müziği, Viyolonsel eğitimi, Viyolonsel öğretimi, Saz semai, Peşrev

\section{Introduction}

Beginning from the 19th century when Western Classical Music put down roots in the Ottoman Empire, various Western Music instruments have been introduced to Turkish Music. ${ }^{1}$ Developed in the 16th century in Europe and introduced by orchestras to royal palaces in the 19th century, the cello was first used in Turkish maqam music in the early 20th century. In the

\footnotetext{
1 Ahmet Tohumcu-Nilgün Doğrusöz, "Gelenekselden Popülere 20. Yüzyıl Türk Makam Müziği Üretimlerinde Değişimin Izleri”, Porte Akademik: Journal of Music \& Dance Studies, 8, 2013, pp. 26, 27.
} 
Ottoman age, the cello was introduced into palace orchestras and chamber music ensembles and also used in fasil performances of the Fasl-1 Cedid (the New-Style Ensemble). ${ }^{23}$

"The earliest cello recordings of Turkish maqam music available belong to Tanbûri Cemil Bey" ${ }^{4}$ Cello performance in Turkish music, which was first introduced by Tanbûri Cemil Bey and followed by his son, Mesut Cemil Bey, has become a tradition thanks to their great contributions. The surviving cello recordings of Tanbûri Cemil Bey and Mesut Cemil Bey give an idea about their performance styles. We have those cello recordings available at hand and they are crucial learning materials that contribute to cello education and set an example in terms of how cello can be used in Turkish Music.

Whereas, in terms of 'professional music education', Turkish Music conservatories provide cello classes in the field of Turkish Music. In addition, Turkish Music is - partly included in cello curricula at some faculties of education and faculties of fine arts as well as in individual instrument-cello classes. Değirmencioğlu and Ararpgirlioğlu indicated that the institutionalized cello classes started at Istanbul Technical University in 1976 and are now provided by nearly all of the Turkish Music conservatories. ${ }^{5}$ Upon a review on the institutional cello teaching process since then, they have also revealed that a repertoire of vocal pieces in traditional Turkish Music and mostly a repertoire of instrumental pieces are used for cello teaching in the field of maqam music. The instrumental forms used in Turkish Music, which are known to be more commonly used in cello teaching, will be briefly addressed.

The instrumental forms in the repertoire of the traditional Turkish Classical Music are peşrev, methal, saz semai, taksim, zeybek, sirto, longa and mandra. Whereas, the instrumental forms in the repertoire of the traditional Turkish Folk Music can be listed as follows: halay, horon, zeybek, bar, semah, karşılama, çiftetelli, hora, bengi, kasap havast. ${ }^{6}$ This study is restricted to saz semais and peşrevs - as it was found out during the preliminary interviews that all of the participants used saz semais and peşrevs in teaching -. None of the other instrumental pieces were included in the scope of the study as they were not in use by all of the interviewed participants in cello teaching.

Below are listed some of the definitions for saz semais and peşrevs, which have a quite significant role in Turkish Music and constitute the scope of the study, as indicated in glossaries and the literature: The word peşrev is defined in the current dictionary of Turkish Linguistic Society as "the piece performed after the introductory taksim and before the actual instrumental or vocal piece in Turkish Classical Music". "The word peşrev literally means "that which comes first'. A classical fasil starts with a peşrev. A peşrev is composed of movements which are called 'hâne'. A teslim or mülâzime, used for repetition, comes after each hâne". ${ }^{8}$ In a peşrev, the composer is supposed to possess mastery in building the melodic pattern of the maqam between motifs and properly display his skill in his art. ${ }^{9}$ The dictionary of Turkish Linguistic Society defines saz semai as "the instrumental closing movement of a fasil in Turkish

\footnotetext{
${ }^{2}$ Leyla Saz, Anılar: 19. Yüzyll Saray Haremi. İstanbul: Cumhuriyet Kitap Kulübü, 2000, pp. 74.

${ }^{3}$ M. Emin Soydaş-Ş. Şehvar Beşiroğlu, "Osmanlı Saray Müziğinde Yaylı Çalgılar", ITTÜ Journal/b, Volume: 4/1, 2007, pp. 9, 10.

${ }^{4}$ Yelda Özgen Öztürk- Ş. Şehvar Beşiroğlu, "Viyolonselin Türk Makam Müziğine Girişi ve Tanburi Cemil Bey", ITÜ Dergisi /b Volume: 6/1, 2009, pp. 31.

${ }^{5}$ Levent Değirmencioğlu-Hasan Arapgirlioğlu, "Makamsal Viyolonsel Öğretiminde Popüler Müzik Eserlerinden Yararlanma: (Orhan Gencebay Örneği)", Journal of Erciyes University Social Sciences Institute, Volume: 2/31, 2011, pp. 200.

${ }^{6}$ Ülkü Özgür-Salih Aydoğan, Gelenekten Geleceğe Makamsal Türk Müziği, Arkadaş Publishing, Ankara 2015, pp. 36.

${ }^{7}$ TDK, http:॥www.tdk.gov.tr/, date of access: 28.01.2019.

${ }^{8}$ Ü. Özgür- S. Aydoğan, ibid., pp. 37.

${ }^{9}$ M. Ekrem Karadeniz, Türk Musikisinin Nazariye ve Esasları (No:238), Türkiye İş Bankası publications, Ankara 1984, pp. 159.
} 
Classical Music" ${ }^{10}$. Saz Semâis refer to instrumental pieces that are often performed after yürük semais and that form the final part of the fasil. They typically consist of four movements called hâne, with the teslim repeated at the end of each hâne. "Similarly to peşrev, saz semai is a form with repetitions, built in the pattern AB CB DB EB. What differs saz semai from peşrev is that the former is built solely in aksak semai, which is a ten beat (10/8) usûl. Traditionally, part E involves a change in beat". ${ }^{12}$ As can be seen from the definitions above, peşrevs and saz semais differ from each other in terms of their usûl structures, the parts in which they are performed and their purpose of use although they have a number of similarities as they both consist of movements (hâne) and a teslim, they are composed in the form of long instrumental pieces in a particular maqam, with different maqam geçkis in movements 2, 3 and 4. Saz semais and peşrevs are often used for teaching maqams and repertoires of Turkish Music as well as for teaching the instruments used in Turkish Music.

Öztuna indicated that the availability of instrumental pieces in Turkish Music fall behind vocal pieces. ${ }^{13}$ On the other hand, there are composers who made efforts to fill the gap in the field by composing instrumental pieces in Turkish Music. For instance, almost all of the pieces composed by Gazi Giray Han and Kantemiroğlu in Turkish Music are in the form of peşrevs and saz semais. Nevertheless, even today, instrumental pieces are still few in number in comparison with vocal pieces. However, another controversial topic, apart from the quantity or quality of the pieces, is whether instrumental pieces are in harmony with the technical characteristics of the instruments. As confirmed by Torun's statement: "There is a need for composition of pieces which conform to the characteristics and styles of our instruments, revealing the techniques specific to them and pushing the limits of the instrument”, it is obvious that suitable pieces should be composed for respective instruments. ${ }^{14}$ Since instrumental pieces in Turkish Music are not composed specifically for particular instruments or by taking their technical characteristics as a basis, a number of problems are experienced in the performance of instrumental pieces. This study examines the problems experienced in the performance of peşrevs and saz semais in the context of cello, with reference to opinions, approaches and suggestions of experts in the field of cello teaching about the role and importance of the performance of such pieces in teaching.

The literature contains numerous studies carried out on instrumental Turkish Music pieces in various forms and various performances about Turkish Music. ${ }^{15}$ There are also studies

\footnotetext{
10 TDK, ibid.

${ }^{11}$ M. E. Karadeniz, ibid., pp. 159.

12 Ü. Özgür- S. Aydoğan, ibid., pp. 40.

${ }^{13}$ Yılmaz Öztuna, Büyük Türk Musikisi Ansiklopedisi (Vol.2.), Kültür Bakanlığı Publications, Ankara 1990, pp. 269.

14 Mutlu Torun, "Türk Müziğinin Gelişimi Üzerine Birkaç Fikir", http://www.turkishmusicportal.org/tr/makaleler/turk-muziginin-gelisimi-uzerine-birkac-fikir, date of access: 14.01.2019.

${ }^{15}$ Gülçin Yahya, Ünlü Virtüoz Yorgo Bacanos'un Ud Taksimleri (Taksim Notaları, Analiz ve Yorumlar) (Vol. 2980), Kültür Bakanlığı Publications, Ankara 2002, pp. 1-280; Bariş Bozkurt,“ An Automatic Pitch Analysis Method for Turkish Maqam Music”, Journal of New Music Research, Volume: 37/1, 2008, pp. 1-13; A. Tolga Özdemir-N. Oya Levendoğlu Öner, "Ud İcra Geleneğinde Cinuçen Tanrıkorur Ekolünün Uzzal Taksim Üzerinden Yansımaları", İn̈nü University Journal of Art \& Design, Volume: 1/3, 2011, pp. 325-337; Gürkan Taşç1, Türk Halk Musikisi Saz Eserlerinin Ortaöğretim Mesleki Keman Eğitiminde Kullanım Olanakları Yönüyle İncelenmesi, Unpublished Master's Thesis, Trakya University, Institute of Social Sciences, Edirne 2012, pp. 1-143; Banu Geboloğlu, "Tanburî Cemil Bey'in Taksîm İcralarında Hüseynî Makamı ve Arel Nazariyatına Göre Bir Karşılaştırma", Rast Musicology Journal, Volume: 3/2, 2015, pp. 994-1007; Cevahir Korhan Işıldak- Banu Geboloğlu, "Tanburî Cemil Bey'in Taksîm İcraları ve Hüseyin Sadettin Arel'in Nazariyatındaki Hüseynî Makamı Uygulamalarının Karşılaştırılması", Rast Musicology Journal, Volume: 3/2, 2015, pp. 994-1007; Yılmaz Kahyaoğlu, Klasik Türk Müziğinde Saz Müziğinin Yeri ve Önemi. İnönü University Journal of Culture and Art, Volume: 1/1, 2015, pp. 57-60; Murat Gürel, “Nubar Tekyay’a Ait Hüzzam Keman Taksiminin Analizi”, Akademik Sanat, Volume: 1/1, 2016, pp. 94-109; Burcu Avcı Akbel, "Stakeholder Opinions on Suitability of Cello Etudes Created from Taksims of Tanburi Cemil Bey in Education. Journal of Education and Practice, Volume: 8/18, 2017, pp. 102-117; Burcu
} 
in the literature that are specifically performed on saz semais and/ or peşrevs. ${ }^{16}$ Some of those studies analyzed and examined instrumental pieces for purpose of analyzing compositions of a composer, ${ }^{17}$ while some other focused on the performance style of a performer, ${ }^{18}$ and some focused on a particular century. ${ }^{19}$ On the other hand, there are some studies in which saz semais and/ or peşrevs are used to examine the playing techniques of Turkish Musical instruments. ${ }^{20}$ There are also other studies that provide a review of music notations or transcription of instrumental pieces into the current notation system. ${ }^{21}$

Those studies in the literature examined instrumental pieces in various ways. However, no study has been discovered in which saz semais and/or peşrevs are examined in the context of cello teaching. This study examined the role, importance and function of saz semais and peşrevs in cello teaching, the title and order of the pieces used in teaching, challenges experienced in the teaching of the pieces and suggestions for solution. Providing a review on saz semais and peşrevs, which are of importance in Turkish Music, in terms of cello teaching, this study is aimed to contribute to cello teaching practices in Turkish Music.

\section{Methodology}

This is a qualitative research aimed at revealing the role, importance and effects of saz semai and peşrev forms in cello teaching. It is indicated by İslamoğlu and Alnıaçık that quantitative data collected in relation to a fact fall short of the ability to satisfactorily explain or

Avc1 Akbel, “A Review on Effectiveness of Cello Etudes Created for Longas and Syrtos”, Eurasian Journal of Educational Research, Volume: 75, 2018, pp. 1-18.

${ }^{16}$ Bülent Anıtsoy, Mevlevi Ayinlerindeki İlk Pesrevlerin Melodik Olarak İncelenmesi, Unpublished Master's Thesis, Süleyman Demirel University, Institute of Social Sciences, Isparta 2006, pp. 1-160; Ercan Akışl1, Reşat Aysu'nun Saz Semailerinin Incelenmesi, Unpublished Master's Thesis, Haliç University, Institute of Social Sciences, Istanbul 2016, pp. 1-154; Çağlayan, Ata Bahri, "Peşrev ile Deramed Biçimlerinin Karşılaştırılması", Rast Musicology Journal, Volume: 5/2, 2017a, pp. 1619-1633; Çağlayan, Ata Bahri, "Peşrevlerde Teslim", Musiqi Dünyası, Volume: 4/73, 2017b, pp. 7855-7859.

17 Arda Kula, Tanbûrî Cemîl Bey'in Saz Eserlerinin Teknik Açıdan İncelenmesi, Unpublished Master's Thesis), Afyon Kocatepe University, Institute of Social Sciences, Afyon 2018, pp. 1-150; Banu Gebeloğlu, "Mesud Cemil Bey’in Saz Eserlerinin Makamsal Analizi”, The Journal of Social Sciences Research, Volume: 13/2, 2018, pp. 305315.

${ }^{18}$ Haluk Bükülmez, “Kemani Sadi Işılay’ın Saz Eseri İcrasının Tahlili”, İdil Journal of Art and Language, Volume: 6/30, 2017, pp.529-584.

${ }^{19}$ Tolga Karaca, "15. Yüzyılda Kullanılmış Olan Bazı Makamların Analizi ve Bu Makamlardan Oluşturulan Saz Semâilerinin Türk Müziği Açısından Değerlendirilmesi”, Rast Musicology Journal, Volume: 5/2, 2017, pp. 16341654.

${ }^{20}$ Emrah Tuncel, Klasik Kemençe Sazında Pozisyon ve Yay Bağlarının Incelenmesi (Saz Semaisi, Peşrev ve Zeybek Formları Üzerinde Parmak Pozisyonları ve Yay Bağları Uygulanarak Bu Çalışmanın Klasik Kemençe Sazına Getireceği Faydaların Belirlenmesi), Unpublished Master’s Thesis, Selçuk University, Institute of Social Sciences, Konya 2008, pp. 1-36; Yılmaz Kahyaoğlu, Kanun Sazı Öğretiminde Klasik Türk Müziği Saz Eseri Formlarının Fonksiyonlarının İncelenmesi, Unpublished Phd Diss., İnönü University, Institute of Social Sciences, Malatya 2011, pp. 1-200; Göksel Baktagir, Kanun Sazında Sağ ve Sol El İ̧̧in Yazılmış Teknik Geliştirici Etütler ve Saz Eserleri, Unpublished PhD Diss., İstanbul Technical University, Institute of Social Sciences, İstanbul 2014, pp. 176; H. Serdar Çakırer, "Reşat Aysu'nun Nihavend Saz Semaisinin Ud Öğretimindeki Temel Davranışlara Yönelik İçerik Analizi”, İdil Journal of Art and Language, Volume: 5/20, 2016, pp.275-292; Gamze Nevra Köroğlu- Sema Sevinç, "Klasik Kemençe Eğitiminde Kullanılan Saz Semailerinin III. Hânelerine Yönelik Hazırlanan Alıştırmaların Öğrenci Başarı Düzeylerine Etkisi”, Fine Arts (NWSAFA), Volume: 12/4, 2017, pp. 249-271.

${ }^{21}$ Sami Dural, "Ali Ufkî, Kantemiroğlu ve Kevserînin Müzik Yazılarının Türk Müzik Geleneği Bağlamında Uzzal Peşrevi Üzerinden İncelenmesi”, Rast Musicology Journal, Volume: 2/1, 2014, pp. 147-162; Gökhan Yalçın, "Nâyî Osman Dede'nin Nota Defterinden Üç Saz Eserinin Müzik Yazısı Açısından İncelenmesi”, Rast Musicology Journal, Volume: 5/1, 2017, pp. 1447-1473; Mine Yener, "Hamparsum Defterinden Günümüze Musi'nin Sazkar Saz Semaisi”. Rast Musicology Journal, Volume: 3/2, 2015, pp. 877-888; Emir Murat Küçük, Hammamizâde İsmail Dede Efendi'nin Üniversitesi Nadir Eserler Kütüphanesi Hamparsum Defterlerinde Yer Alan Peşrev ve Saz Semai Formunda Eserlerinin Günümüz Nota Yazısına Çevrilmesi ve İncelenmesi, Unpublished Master's Thesis, Haliç University, Institute of Social Sciences, İstanbul 2015, pp. 1-120; Tevfik Bilen, Neyzen Dede Emin Efendi'nin Hamparsum Notasıyla Yazdı̆̆ Âyin Defterindeki Peşrev, Son Peşrev ve Son Yürüklerin Günümüz Notasına Çevirisi, Unpublished Master’s Thesis, Gazi University Institute of Fine Arts, Ankara 2016, pp. 1-350. 
measure such fact and providing in-depth information. ${ }^{22}$ The qualitative research method was used in this study in order to acquire more in-depth information.

\subsection{Research Design}

This study utilized phenomenological methodology. Phenomenological design is a method that focuses on the assessment of a lived experience. ${ }^{23}$ Phenomenology is an attempt to primarily identify the world experienced by individuals and to describe the essence of lived experiences. ${ }^{24}$ In the scope of this study, the use of saz semais and peşrevs in teaching was examined in detail with reference to the experiences, observations, opinions and suggestions of experts in the field of cello teaching.

\subsection{Study Group}

The study group consists of ten persons who currently work or have worked as cello instructors at universities in various cities across Turkey. As a purposeful sampling method, maximum variation sampling method was employed in the selection of the study group. The purpose of the maximum variation sampling method is to create a relatively small sample group and to reflect, at a maximum level, the diversity of individuals who may be involved in the problem subject to the study. ${ }^{25}$ In line with this purpose, the study group consists of female and male participants of different ages and educational levels, resident in various regions across Turkey and having at least two years of experience in cello teaching at Turkish Music conservatories. By ensuring diversity in criteria such as age, educational level, sex and location, the purpose is to address as many different circumstances as possible.

Table 1. Details of Participants

\begin{tabular}{llllll}
\hline $\begin{array}{l}\text { Participant's } \\
\text { Identification } \\
\text { Code }\end{array}$ & Gender & Age & Level of education & Geographic region & $\begin{array}{l}\text { Date } \\
\text { Interview }\end{array}$ \\
\hline E1 & & & & \\
E2 & Female & 39 & Master's degree & Central Anatolian Region & 15.11 .2018 \\
E3 & Male & 28 & Master's degree & Central Anatolian Region & 20.11 .2018 \\
E4 & Male & 37 & Bachelor's degree & Mediterranean Region & 09.11 .2018 \\
E5 & Female & 45 & Master's degree & Aegean Region & 10.11 .2018 \\
E6 & Male & 55 & Bachelor's degree & Aegean Region & 21.11 .2018 \\
E7 & Male & 49 & PhD & Black Sea Region & 14.11 .2018 \\
E8 & Male & 52 & Bachelor's degree & Southeastern Anatolia Region & 09.11 .2018 \\
E9 & Male & 36 & PhD & Eastern Anatolia Region & 26.11 .2018 \\
E10 & Male & 29 & Bachelor's degree & Central Anatolian Region & 12.01 .2019 \\
\hline
\end{tabular}

Note: All participants are teaching in universities in Turkey.

\subsection{Tools and Methods for Data Collection}

Data were collected through interviews. "The purpose of a qualitative interview is to address the subject of study from the perspective of interviewees and to find out how and why

\footnotetext{
${ }^{22}$ Ahmet Hamdi İslamoğlu-Ümit Alnıa1k, Sosyal Bilimlerde Araştırma Yöntemleri (Fifth edition), Beta Publishing, İstanbul 2016, pp. 215.

23 Melanie A. Jasper, "Issues in Phenomenology for Researchers of Nursing”, Journal of Advanced Nursing, Volume:19/2, 1994, pp. 309-314; Sue Miller "Analysis of Phenomenological Data Generated with Children as Research Participants”, Nurse Researcher, Volume: 10/4, 2003, pp. 68-82.

${ }^{24}$ Rose, Pat, et al., "Academic Rigour in The Lived Experience of Researchers Using Phenomenological Methods in Nursing”, Journal of Advanced Nursing, Volume: 21, 1995, pp. 1123-1129.

${ }^{25}$ Ali Yıldırım-Hasan Şimşek, Sosyal Bilimlerde Nitel Araştırma Yöntemleri, Seckin Publishing, Ankara 2008, pp. 108.
} 
the interviewees formed their perspectives". ${ }^{26}$ Therefore, the study used less structured procedures and open-ended questions. In order to acquire in-depth information about the subject of the study, the researcher created a semi-structured open-ended interview form consisting of six questions. Two experts specialized in the fields of educational sciences and literature were referred to for their opinions throughout the process of preparation of the interview form, which was put into final form with the revisions mentioned. The interview questions are as follows:

1) What do you think about the place and use of saz semais and peşrevs in the teaching of cello?

2) What are the most challenging subjects in which the students perform saz semais and peşrevs?

3) What are the most important points on playing saz semais and peşrevs?

4) What elements do you consider when choosing saz semais and peşrevs work in the course?

5) What are your suggestions in order to perform saz semais and peşrevs in a better technique and musicality?

6) Please specify if you have different suggestions.

The interviews were audio recorded with the consent of the participants. Making use of the advantages of a semi-structured interview, the interviewer directed different questions to the interviewees with the aim to acquire more information depending on the course of the interview. The data obtained was transcribed into written form in computer environment and made available for analysis.

\subsection{Data Analysis}

The data in this study were analyzed by using the content analysis method. "Content analysis is a qualitative data analysis technique aiming at acquiring such concepts and relations that can describe the data collected". ${ }^{27}$ At the first stage, the data transcribed into written form was edited. At the second stage, the qualitative data software NVivo 12 was used to encode data; themes were created out of the data encoded, and categories were made of the themes; the data was identified and interpreted under the title of findings. At the third stage, the data encoded were checked for several times on different dates by the researcher, with necessary corrections made. At the fourth stage, titles of themes and the sentences encoded was sent to two experts in the field of music education and research methods, and the findings were put into final form with the data obtained. The interviewees in this study were anonymized by replacing their names with codes such as E1, E2, etc.

\subsection{Validity-Reliability}

In order to ensure external reliability in a qualitative research, the results achieved must always be confirmed by the data collected and the reader must be provided with reasonable explanations. ${ }^{28}$ Accordingly, the research data was subject to numerous checks at different times with a view to increase external reliability of the study; also, a detailed explanation was provided about the research method, data collection, processing, analysis, interpretation, and results achieved. Within the context of a qualitative research, internal reliability is defined as the question of whether other researchers will be able to achieve the same results by using the same

\footnotetext{
${ }^{26}$ Sait Gürbüz-Faruk Şahin, Sosyal Bilimlerde Araştırma Yöntemleri (Fifth edition), Seçkin Publishing, Ankara 2018, pp. 430.

${ }_{27}$ Ünsal Sı̆̆rı, Nitel Araştırma Yöntemleri. Beta Publishing, İstanbul 2018, pp. 280.

${ }^{28}$ Ü. Sığrı, ibid., pp. 138.
} 
data. ${ }^{29}$ In the scope of this study, two experts in the fields of music education and research techniques were referred to for their opinions. The statements encoded with theme titles were sent to the experts, asking them to match the themes with the statements encoded. The statements and themes which do and do not match each other were identified, corrected and put into final form in line with the experts' opinions.

In qualitative researches, validity means that the researcher addresses a case objectively and as it is. ${ }^{30}$ In order to ensure validity in this research, the interviewees were directed the same questions in different forms at different times throughout the interview in an attempt to revise self-contradictory statements and reveal actual opinions of the participants. Furthermore, a purposeful sample group was selected and diversified in order to ensure generalizability. Also, efforts were made to increase validity of the research by a number of ways such as direct quotation, description of data at an adequate level and use of the data analysis software NVivo 12.

\section{Findings}

\subsection{The Importance and Role of Saz Semais and Peşrevs in Cello Teaching}

The importance and role of saz semais and peşrevs in cello teaching were examined in this section. All of the participants stated that it was useful and essential to use saz semais and peşrevs in cello teaching in Turkish Music. On the other hand, there are different opinions as to the benefits provided by saz semais and peşrevs. Some of the participants argue the contribution of saz semais and peşrevs to teaching not only in terms of technical aspects but also maqams. Among the participants holding the same opinion, E7 stated as follows:

I think that saz semais and peşrevs are the most effective forms written for the instrumental repertoire of Turkish Music. As instrumental pieces solely have a melodic structure, they have more melodic intensity. Therefore, I think that instrumental pieces are of importance as they contribute to cello teaching both in terms of maqams and technical aspects.

Similarly to E7, E3 stated as follows: "I think that instrumental pieces are important for cello teaching because practicing instrumental pieces in maqam music enables learning on more solid foundations in terms of control over the instrument and ear training." The above mentioned statements of E7 and E3 emphasize the importance of saz semais and peşrevs for cello teaching both in terms of maqams and technical aspects.

Regarding the subject, E4 stated as follows: "I think that instrumental pieces are important in cello training and cello education needs to make more intensive use of such pieces. Instrumental pieces, primarily including peşrevs, are crucial for learning maqams. It is useful to practice instrumental pieces in many aspects such as enriching the repertoire, learning maqams and usûls, etc.”. E1 and E2 reported similar statements. Rather than addressing the effects of the use of saz semais and peşrevs in teaching on the cello technique, E1, E2 and E4 made the above mentioned statements to report their opinion that teaching such pieces would contribute to knowledge of maqams and usûls, enrichment of the repertoire and improvement of musicality.

On the same subject, E8 pointed out to the significance of teaching instrumental pieces, while discussing that teaching such pieces would not be of more use than enriching the repertoire of learners unless the pieces were composed solely for the cello. E5 also reported similar statements. The statements made by E5 and E8 can be interpreted to mean that the instrumental pieces currently available fall short of the ability to provide technical benefits.

\footnotetext{
${ }^{29}$ Ali Yıldırım-Hasan Şimşek, Sosyal Bilimlerde Nitel Araştırma Yöntemleri (10th edition), Seçkin Publishing, Ankara 2016; Ü. Sığrı, ibid., pp. 139.

${ }^{30}$ Jerome Kirk-Marc L. Miller, Reliability and Validity in Qualitative Research (Vol.1), Sage Publications, London 1986.
} 
Most of the participants in general think that such pieces are efficient and useful in terms of teaching maqams and enriching the repertoire.

\subsection{Difficulties Experienced}

The theme of difficulties experienced is frequently addressed and most commonly reported by all of the participants. The most commonly reported topics of difficulty include correct intonation, correct use of positions and correct bow technique. In the view of the statements made by the participants, the topics most commonly reported by the students in terms of difficulties are presented in form of a table below:

Table 2. Difficulties Most Commonly Experienced in the Performance of Saz Semais and Peşrevs

\begin{tabular}{|l|l|l|l|l|l|l|}
\hline $\begin{array}{l}\text { Difficult subjects } \\
\text { to students }\end{array}$ & Intonation & Positions & Use of spring & $\begin{array}{l}\text { Turkish Music } \\
\text { maqams }\end{array}$ & Agility & Nuances \\
\hline Participants $\Rightarrow$ & $\begin{array}{l}\text { E1, E5, E6, } \\
\text { E8, E9 }\end{array}$ & $\begin{array}{l}\text { E1, E5, E6, } \\
\text { E9 }\end{array}$ & $\begin{array}{l}\text { E1, E2, E4, } \\
\text { E7 }\end{array}$ & E1, E7, E9 & E3, E4, E7 & E2, E9 \\
\hline
\end{tabular}

Note: The topics on which at least two participants reported their opinions are indicated in the table.

Most of the participants reported that students had more difficulties in performing saz semais in comparison with peşrevs, while some other participants stated that the level of difficulty varied depending on the piece. For instance, E5 stated that saz semais were relatively more difficult: "Peşrevs are more static, they can be performed more comfortably. Saz semais are more dynamic than peşrevs." On the same subject, E1 stated: "In terms of rhythm, peşrevs are easier to play - as they are usually played by a single stroke on a four beat rhythm. Saz semais are mainly composed with usûl structures such as 10/8, 9/8, so students usually have more difficulties in performing saz semais than peşrevs.” The statement above explains the reason for the difficulty experienced with saz semais, which is described as 'dynamic' by E5.

There are statements addressing the differences between notation and performance in Turkish Music, with emphasis on the fact that the students have difficulties in envisaging which microtones they must play when performing a particular piece. According to E6, the students have the most difficulty with the maqams Uş̧̧ak, Hüzzam, Karcığar while E8 stated that they have the most difficulty with the maqams Rast, Uşşak. As for the use of positions and transitions between positions, the positions which the students have the most difficulty with are stated as the 2nd and 3rd positions, the 3rd position, and the 5th, 6th and 7th positions, as reported by E1, E5 and E6, respectively.

Regarding the use of the bow, E2 pointed out to incorrect use of the bow techniques while E4 reported having difficulties in playing legatos. On the same subject, E1 stated: "The tempered system makes it easier for the student to use the bow correctly, while Turkish Music requires playing techniques that involve the characteristics of maqams. While playing a piece in Turkish Music, it is likely that the student will fail while trying to be careful with maqams, bow technique, rhythm and sound at the same time. This will result in an incorrect use of the bow." E7 stated: "Usuls in Turkish Music have their strong beats scattered in different patterns throughout the piece and the pieces do not contain bow signs, so the students have difficulties in determining how to match bow pull- push movements with strong beats”. Regarding the solution of this problem, E7 stated that each individual piece needed to have their bow signs written, which is not very practical.

As for the knowledge of maqams, E7 stated: "Students have difficulty with maqams and maqam transitions if the maqams have complicated structures. A solution for this problem is to memorize the maqam over time.” Additionally, E7 reported that students with inadequate 
knowledge of maqams mostly had difficulty with the first hâne, teslim and the second hâne of saz semais and peşrevs. The mentioned observation of E7 is justified by the fact that the first hâne, teslim and the second hâne of saz semais and peşrevs reflect the characteristics of the maqam in which the piece is composed. However, other hânes also involve transitions between maqams. This means that students with inadequate knowledge of maqams will have the same difficulty with other hânes. It is noteworthy that E7 suggests 'memorization of maqams' as a way of solution for the mentioned problems. E7 thinks that 'memorization' is of importance, which is also evidenced by his statement: "For instrumental pieces, I instruct students to memorize the teslim of 1 hâne." E7 suggests memorization as a solution for the problems experienced with maqams. As for the knowledge of maqams, E1 reported that students usually fail to transfer their theoretical knowledge into their instrument due to their insufficient knowledge of maqams.

As for agility, E7 stated: "They usually have difficulty with playing small notes separately and with agility while keeping the tempo stable. Therefore, they usually try to use the legato technique for the parts require agility". With the mentioned statement, E7 pointed out to the fact that students have difficulties with transitions that require agility, and that they use the 'legato' technique in order to make those parts easier to play. E3 stated as follows: "The cello is not an agile instrument in terms of the use of the bow. The performer can achieve required agility only with a high level of proficiency." On the same subject, E4 reported that students usually have more difficulties with the final hâne of peşrevs and saz semais - which require agility and changes in usûls - in comparison with other hânes. E7, confirming E4's statement that students experienced difficulties with the final hânes of peşrevs and saz semais, explained the reason of such difficulties with the fact that the final hâne often contained a completely different melody from that of the first hâne, teslim and the second hâne.

As for nuances, E5 reported that the piece could not be enriched and was mostly played monotonously, and stated as follows: "Music is not something like that, it can be smooth or rough at times. For this reason, I think that nuances should be written on the pieces”. Pointing out to the challenges regarding nuances with this statement, E5 made a suggestion for the solution of this problem. E2, viewing the subject from a further aspect, emphasized that nuances should be performed collectively in ensemble performances; this creates an awareness on musicality in collective performances.

Apart from the topics discussed above, several different subjects were addressed as difficulties experienced by students, which were each reported by only one participant. For instance, there are problems with the ability to give the feeling of the piece and play smoothly as reported by E1, ornaments and articulation as reported by E8, and individual characteristics style as reported by E7.

\subsection{Key Points of Consideration}

Research data reveals that, despite occasional similarities, the key points of consideration often vary among the participants. The topic which is most commonly addressed by the participants is the need for composition of pieces suitable for the instrument. Regarding the subject, E8 stated as follows: "It is quite important to teach an instrumental piece in Turkish Music; however, unless such piece is composed for cello, then it would be no more than a mere performance of the piece. The pieces should also have technical contributions to cello performers". E5 reported that the difference in levels of difficulty between hânes led to challenges in selection and performance of the pieces that match the student's level of proficiency, and underlined the need for pieces that should be specifically composed for the particular instrument.

Regarding the points of consideration, E7 stated: "To me, it is quite important to be able to reflect the style and individual characteristics of traditional music in the best way when 
performing instrumental pieces on the cello.” This statement of E7 underlines the significance of style in the performance of Turkish Music. E2, on the other hand, addressed different topics and reported as follows:

\begin{abstract}
The cello is a Western Music instrument and there are cello methods that were written centuries ago. I think that students should build basic technical proficiency by using those methods before they proceed to practicing Turkish Music. I also think that students should play in ensembles. Students will stay more committed to practicing their instrument when they have the audience to view them properly performing pieces of music. And when they stay more committed, they will provide more proper performances. Eventually, this will enhance the quality of works performed.
\end{abstract}

With this statement, E2 lays an emphasis on the necessity of mastering the Western Music techniques and developing a certain level of technical control before proceeding to practicing Turkish Music. On the same topic, E4 stated as follows: "Passages that involve agility or require the performer to play the notes separately are the very reason that students fail to perform the piece correctly - due to the problem with right hand control -. Therefore, students need to do more practice on right hand control.” The statement, describing the situations in which students experience problems with right hand control, is quite informative in terms of what needs to be done to overcome the problems experienced. While the participants E2, E4, E5, E7 and E8 suggested that Western Music methods should be used, the participants E6 and E9 stated that a method specific to Turkish Music should be used and that they experienced the shortcomings of the unavailability of such method.

\title{
2.4. Selection of Pieces of Music
}

Selection of the pieces of music for cello teaching in the field of Turkish Music and their order in teaching varies depending on instructor and institution. This section examines which criteria are taken into consideration when selecting saz semai and peşrev pieces and sequencing them in teaching. On this subject, E9 stated as follows: “The criteria I take into consideration when selecting a piece are whether the piece fully embodies the characteristics of the maqam and whether it contributes to the development of students. I think it would be helpful to start with simple maqams and instrumental pieces composed in Aksak Semai usûl.” Regarding the selection of pieces for practice, the criteria taken into consideration by E6 include levels of difficulty of the pieces rather than the maqams, and the participant suggests a teaching process with a progress from easy to difficult. E3 stated that the pieces of music to be selected should match the level of students. E10, addressing the subject from a different point of view, stated: "Turkish Music pieces are not instrument-specific compositions, so when we select a particular piece, it is probably because we have decided that 'it sounds good on the cello'."

E7 considered the subject from the perspective of student motivation, and stated: "I usually select a score among those suggested by the students since it is likely that they have listened to that score earlier, so they already know its tune and they will do more practice on it because they love that score.” This statement of E7 reveals his tendency towards learner-centred education. Students will have increased motivation when they perform the pieces they are familiar with, and their learning will be based on the principles 'known to unknown' - 'near to afar'. However, learners are not capable of assessing the respective technical requirements of each individual piece, and identifying the particular pieces that match their respective cognitive readiness levels. To what extent should a learner have autonomy in selecting the learning materials? How could it be possible to ensure an effective teaching without the student involved? It is possible to interpret these questions in different ways with different perspectives. Here, what matters is to be able to act in harmony with the current situation and conditions.

E5 brought a different perspective to the topic of selecting a piece of music, and stated as follows: "Compared to the topic of which pieces of music are performed by students, what is actually important for students is to improve their ability to perform those pieces. I think that 
what matters is to provide the student with required proficiency so that they will become able to perform the pieces. So, what we should do for the students is to teach them to fish, and then let them catch the other fish". With the statement above, E5 pointed out to the fact that providing students with adequate technical and musical knowledge is more important than selection of pieces of music for them.

\subsection{Suggestions by Participants}

The participants in the study made various suggestions for students, instructors, composers and researchers. Those suggestions are of importance in the sense that they are meant to be a solution to the problems experienced in the use of saz semai and peşrev forms in cello teaching.

\subsubsection{Suggestions for Instructors}

Most of the suggestions made in the scope of the study were for instructors. The participants suggested that instructors should start with teaching the Western Music methods, identify the levels of difficulty of the pieces and take the principle 'easy-to-difficult' as the basis in their teaching, prepare etudes and finger exercises for the pieces selected for teaching, accompany the learner when playing pieces and etudes, display behaviours that will increase learner motivation and perform teaching accordingly, identify the pitches that give the best sound for a particular piece of music and teach those pitches, and assign tasks to students.

E2, E3 and E4 suggested that learners should proceed to Turkish Music practices in master- apprentice relationship only after they have been equipped with adequate basic knowledge. E3 and E5 suggested that, in line with the principle 'simple to complicated, easy to difficult', instrumental pieces to be selected and taught should match the student's level of proficiency. On this subject, E8 reported as follows:

First of all, instrumental pieces should be selected and categorized by performers who are expected to have a good knowledge of Western Classical Music as well as Turkish Music and a mastery of related techniques; the level of difficulty should be identified, and technical expressions should be written on the notation of such pieces. Even the special techniques used in Turkish music should be discovered and instructions should be provided on how to apply those techniques... Turkish music performers should be analyzed in technical and musical terms; various theories should be constructed and taken as the basis in teaching.

The suggestions of E8 involve not only identifying the levels of difficulty of the pieces but also discovering the techniques required by those pieces and ensuring that the sheet music includes related technical annotations. Furthermore, E8 suggests that instructors should examine the performance styles of cello performers in the field of Turkish Music in order to construct theories on those styles and to provide cello classes on the basis of the theories constructed. This suggestion is of great value as it focuses on ensuring sustainability of the performance styles of influential performers in Turkish Music performances on the cello. With regard to ascertaining the levels of difficulty of the pieces, E6 stated as follows:

For example, Nihavend saz semai composed by Mesud Cemil requires a level of proficiency which is suitable for senior students of Turkish Music conservatories. The Maqam Nihavend course is usually given for sophomore students at our conservatories, but Nihavend Saz Semai by Mesud Cemil is not included in their curricula. So how will the students improve their instrumental skills? For this reason, instructors should not only consider the levels of difficulty of the maqams but also identify the maqams of the most difficult and complicated pieces when determining the order of priority in teaching the maqams. In order to ensure teaching to be in conformity with the principle 'easy to difficult', we should arrange the order of priority in such a manner that the most difficult pieces will be introduced to the learner in the final stages of learning. Additionally, all conservatories should have the same maqams and course contents in their curricula. 
This statement of E6 includes the suggestion that the order of priority for the maqams should be determined depending on the levels of difficulty of the pieces to be included in the curricula, rather than the maqams themselves. Given the fact that any musical score composed in any maqam may be difficult, it is obvious that challenges may be experienced with classification if such classification is solely based upon this criterion. On the other hand, E6 suggested that the same maqams should be included in the curricula of conservatories, which underlines the importance of the systematization of education.

There are also other participants who mentioned the importance of etudes in teaching, and the need to write etudes in conformity with the scores. For instance, E9 suggested that the classes should involve, prior to the performance of a piece, etudes on the progression of the respective maqams and exercises on positions. E10 stated as follows: "If related etudes and exercises are not annotated on the pieces - which is the fact -, then it will be harder and take longer to practice and perform the pieces", suggesting instructors to write etudes specifically for the respective pieces.

E6, reporting his suggestion that a functional teaching method should be implemented, stated as follows: "Peşrevs are useful if the aim is to teach the progression and the sound of a maqam, while sirtos and longas should be preferred if the aim is to teach agility. Saz semais, on the other hand, involve the both characteristics. Every student should be taught how to perform a peşrev and a saz semai in every maqam they have learned." This statement, including the opinion that teaching should match the purpose, suggests that peşrevs are helpful for teaching the maqams, while saz semais are helpful for teaching both the maqams and agility.

Some of the participants made a number of suggestions to performers and instructors so that they can improve musicality. E5, suggesting that nuances should be added as annotations on sheet music, stated as follows: "...You can add ornaments such as pizzicatos, au talon, punta d'arco, etc., to suitable parts of the piece in order to acquire more different tones, timbres, and textures”. Regarding the subject, E4 stated the following:

Pieces that are suitable for the cello and the pitches on which a better sound is achieved should be determined. Instructors can also work on the interpretation of instrumental pieces. It can be revealed how the techniques learned in Western music can be used and in which parts such techniques can be used - to achieve a good sound -. Moreover, the suitable parts of the piece can be identified in order to use the pitches that match them on those parts.

With the statement above, E4 suggested that musicality should be increased and due attention should be paid to this topic in teaching. The suggestions of E4, especially with regard to the interpretation of instrumental pieces and selection of playing techniques are important as they contribute to the formation of musicality. E5, referring to the exercises on transposition, stated: "In order to be able to adapt the fourth and fifth intervals in Turkish Music to transposed performance, the students may be asked to play those intervals on different pitches". With the statement above, E5 suggested instructors to act as a guide for the learner in learning the transpositions.

There are also some participants who made suggestions for instructors about style, accompaniment and motivation. E7, laying an emphasis on the significance of traditional style, mentioned the importance of accompaniment for the learner as well as motivating the learner for the class - cello and made related suggestions. E6 suggested assigning tasks to the learner, and stated: "I want my senior students to compose a saz semai in the maqams they have learned so far. This will help the students train themselves, practice and introduce their compositions by performing them before an audience”. This suggestion of E6 provides an emphasis on the principle of 'engaging students in learning', which also constitutes a requirement of studentcentred learning method. 


\subsubsection{Suggestions for Learners}

The participants made a large number of suggestions for learners. The majority of the participants suggested that learners should listen to Turkish Music pieces - recordings. E3 suggested that learners should listen to both instrumental and vocal pieces a lot in order to avoid challenges with the sound. E7, pointing out to the insufficient number of cello recordings available as reference sources, suggested that learners should listen to old audio recordings of performances accompanied by ensembles. E7, indicating that individual performances involve lots of extra ornaments apart from the notation, stated that it he does not approve such type of performance, and suggested that the students should listen to ensemble performances. On the other hand, E10 noted that Turkish music notation does not fully reflect the actual performance, and suggested that learners should listen to the recordings of Turkish Music. E3, often addressing the importance of technical practice in addition to listening, suggested the following for learners:

Let's think of the bow as the engine of a car; the more robust the engine is, the faster and more comfortably you can drive. When you want to reflect an emotion on your piece, it is about how you use the bow, not about the touch. Therefore, they need to practice etudes and bow techniques a lot and also make use of practice methods. Briefly, I suggest that learners should practice the cello methods, focus on bow practices, listen to Turkish music a lot and try to practice what they have listened to.

This statement of E3 including an analogy between the cello bow and a car engine is worthy of note. With the analogy, E3 pointed out that learners should improve their right hand techniques which will provide them with comfort and agility. Furthermore, the suggestions of E3 are different from the suggestions of the other participants in terms of the technique and the listening, as well as the importance of practicing the recordings listened. Similarly addressing the importance of practice, E2 stated: "I think it is crucial to work with a good instructor. To motivate my students, I encourage them to listen to the music from the right sources and to take part in concerts and events that will enable them to make more achievements". These are suggestions that note the importance of listening and practicing in cello education.

Some of the participants suggested learners to try accompaniment and identify bow movements. Regarding the usûl, E7 advised students to pull the bow on strong beats of the usûl. Also suggesting the learner to play along their instructor or an audio recording recommended by the instructor, E7 considered that this would enable the learner to become familiar with accompaniment and solve their problems with intonation and usûl. On the same subject, E1 stated as follows:

I suggest that learners should begin with small and simple maqam exercises and perform seyir and taksim practices in order to best comprehend the maqam. They should practice saz semais and peşrevs meter by meter and hâne by hâne. I advise learners to listen to as many saz semais and peşrevs as possible in the maqam which they currently study. After the instructor has taught several pieces in the related maqam, learners should practice all saz semais and peşrevs in that maqam on different pitches and include them into their repertoire.

This statement of E1 is important in the sense that it is actually a summary of statements made by the other participants on the subject and it contains many advices. E1's suggestion for learners to practice part by part, listen to sources and practice transposition is worthy of note in terms of advising the learner what steps they should take and in which sequence they should take such steps.

\subsubsection{Suggestions for Composers}

Most of the participants made suggestions for composers in scope of the study. For instance, E5 suggested that composers should write instrumental pieces specifically for 
particular instruments. Similarly, E6 pointed out to the insufficiency of cello practice methods in Turkish Music, and noted that the number of instrumental pieces is quite low in comparison with vocal pieces and more instrumental pieces should be composed for development in the performance. Other participants reporting their opinions on the subject made similar statements to those of E5 and E6.

\section{Conclusion and Suggestions}

\subsection{Conclusions}

In frame of this study, all the interviewees addressed the importance of saz semais and peşrevs, stating that they are essential in cello teaching. On the other hand, there are contrasting opinions between the participants on which benefits are provided for the learner by saz semais and peşrevs. Some of the participants think that saz semais and peşrevs have benefits solely in teaching the maqams, while others argue their benefits are in terms of control over the instrument and ear training, or in terms of enriching the repertoire, interpretation and teaching of nuances.

Most of the participants reported that students have more difficulties in performing saz semais in comparison with peşrevs, while some other participants stated that the level of difficulty varies depending on the piece. It has been revealed that students have the most difficulties in providing the correct intonation, correct use of the positions and correct bow technique while performing saz semais and peşrevs. Apart from those indicated, there are also challenges experienced in terms of the knowledge of maqams, agility and nuances. The differences between notation and performance in Turkish Music were addressed, with emphasis on the fact that the students have difficulties in envisaging which microtones they must play when performing a particular piece. In terms of bowing, the most commonly reported problem is with the right hand techniques. In terms of positions, it has been found out that the students have difficulties in using all the positions except the 1st and 4th positions. In terms of the knowledge of maqams, the participants reported that the students had problems with complicated maqams and transitions between maqams. In terms of nuances, they reported that the pieces were usually performed monotonously, without being enriched with nuances. In terms of agility, it was reported that the students usually had difficulties in playing small notes separately while keeping the tempo stable.

Research data reveals that, despite occasional similarities, the key points of consideration often vary among the participants. The participants noted that it was crucial to provide the learner with adequate technical knowledge before proceeding to learning Turkish Music, provide practices for right hand control, teach the usûl and style of traditional music in the best manner, encourage learners to take part in concerts and compose pieces for the cello.

The majority of the participants suggested that Western Music practice methods should be used, while some other participants stated that a practice method specific to Turkish Music should be used and they experienced the shortcomings of the unavailability of such method. Are learners equipped with adequate technical knowledge at the first stage of their cello education by the Western Music methods which have been in use for three centuries? Or is there a need for a different methodological approach for cello teaching in Turkish Music? These questions are controversial topics on cello teaching in Turkish Music with a variety of opinions on them, and they currently remain unanswered. When a method can be discovered to meet the needs, the questions will already have been answered.

Selection of the pieces of music for cello teaching in the field of Turkish Music and their order in teaching varies depending on instructor and institution. It has been revealed under this study that the participants acted on the basis of different criteria in selection of pieces of music. The criteria taken as the basis when selecting pieces of music seem to vary depending on participants; such criteria are reported as follows: conformity with the technical characteristics 
of the cello, fully reflecting the characteristics of a maqam, contributing to the learner, conformity of the sound with the cello, and motivation of the learner. As for the sequence of pieces, the majority of the participants stated that they preferred a teaching process with a progress from 'easy to difficult, known to unknown'. Whereas, some participants noted that particular pieces that match the learner's cognitive readiness level should be preferred.

There are also participants who argue that the important step is not the selection of pieces of music but to help learner become equipped with adequate technical and musical knowledge and skills. This way of thinking may be interpreted to mean that instrumental pieces have no considerable effect on the process of achieving adequate technical knowledge. From this perspective, it is advised that saz semais and peşrevs should be taught after the learner has acquired all necessary technical knowledge. However, Turkish Music Conservatories provide only four years of education. As it takes a long time to learn the maqams and pitches of Turkish Music both in terms of ear training and practice, learners cannot be expected to fully acquire the mentioned technical knowledge and skills. Therefore, saz semais and peşrevs are not only included in the maqams and repertoires of Turkish Music but also used to improve technical and musical skills, as reported by many of the participants. Most of the participants suggested that learners should be allowed to proceed to learning Turkish Music only after they have acquired basic technical knowledge through practice methods. However, when the period of education is taken into consideration, students have only one or two years to acquire basic technical knowledge. Therefore, students usually fail to acquire the full knowledge required to play the cello within the mentioned period of time. As the techniques required to perform saz semais and peşrevs tend to vary by piece, the related pieces should be classified and sequenced by experts in the view of their respective technical and musical elements, so that saz semais and peşrevs will be available for use as technical materials in cello teaching and they will serve the purpose of teaching maqams of Turkish Music and enriching the repertoire.

In frame of this study, the participants made a number of suggestions for students, instructors, composers and researchers with a view to ensure better performance of saz semais and peşrevs, solution of the problems experienced and more efficient use of the pieces in teaching. Their suggestions most often addressed instructors. The suggestions made by the participants for instructors that they should start with teaching the Western Music methods, identify the levels of difficulty of the pieces and take the principle 'easy-to-difficult' as the basis in their teaching, prepare etudes and finger exercises for the pieces selected for teaching, accompany the learner when playing pieces and etudes, ask the learner to practice transpositions, display behaviours that would increase learner motivation and perform teaching accordingly, identify the pitches that give the best sound for a particular musical piece and teach those pitches, and assign tasks to learners.

The majority of the participants suggested that learners should listen to the instrumental pieces - recordings of Turkish Music from the right sources. Additionally, the participants suggested that learners should do technical exercises, practice the piece part by part, match the bow pull movement with strong beats of the usûl, practice transpositions, take part in concerts and events that will enable them to make more achievements, and accompany each other.

Many of the participants also made suggestions for composers in scope of the study. Their suggestions for composers included composition of instrumental pieces specifically for particular instruments, and composition of more instrumental pieces.

\subsection{Suggestions}

It is believed that a uniform curriculum for cello education at all conservatories, in line with a proper sequence of maqams- pieces conforming to the technical capacity of the cello, will contribute to a relatively more systematic teaching across Turkey. Also, in frame of the suggestions made by the participants and the existing requirements, composers are advised to 
compose saz semais and peşrevs specifically for technical characteristics of particular instruments. Additionally, the technical, musical and maqam elements of saz semais and peşrevs should be identified and transformed into etudes, which should be used before teaching the pieces. Such etudes will help overcoming current and potential challenges with saz semais and peşrevs, so that the cello classes will be more systematic and will provide the learner with more achievements in various aspects such as maqams, usûls, techniques, etc..

\section{Bibliography}

Akışlı, Ercan, Reşat Aysu'nun Saz Semailerinin İncelenmesi, Unpublished Master’s Thesis, Haliç University, Institute of Social Sciences, 2016.

Anıtsoy, Bülent, Mevlevi Ayinlerindeki Ilk Pesrevlerin Melodik Olarak Incelenmesi, Unpublished Master's Thesis, Süleyman Demirel University, Institute of Social Sciences, Isparta 2006.

Avc1 Akbel, Burcu, "A Review on Effectiveness of Cello Etudes Created for Longas and Syrtos”, Eurasian Journal of Educational Research, Volume: 75, 2018, pp. 1-18.

Avc1 Akbel, Burcu, "Stakeholder Opinions on Suitability of Cello Etudes Created from Taksims of Tanburi Cemil Bey in Education. Journal of Education and Practice, Volume: 8/18, 2017, pp. 102-117.

Baktagir, Göksel, Kanun Sazında Să̆ ve Sol El İçin Yazılmış Teknik Geliştirici Etütler ve Saz Eserleri, Unpublished $\mathrm{PhD}$ Diss., İstanbul Technical University, Institute of Social Sciences, İstanbul 2014.

Bilen, Tevfik, Neyzen Dede Emin Efendi'nin Hamparsum Notasıyla Yazdĭ̆ Peşrev, Son Peşrev ve Son Yürüklerin Günümüz Notasina Çevirisi, Unpublished Master’s Thesis, Gazi University Institute of Fine Arts, Ankara 2016.

Bozkurt, Bariş. "An Automatic Pitch Analysis Method for Turkish Maqam Music”, Journal of New Music Research, Volume: 37/1, 2008, pp. 1-13.

Bükülmez, Haluk, "Kemani Sadi Işılay’ın Saz Eseri İcrasının Tahlili", İdil Journal of Art and Language, Volume: 6/30, 2017, pp. 529-584.

Çağlayan, Ata Bahri, "Peşrev ile Deramed Biçimlerinin Karşılaştırılması", Rast Musicology Journal, Volume: 5/2, 2017a, pp. 1619-1633.

Çağlayan, Ata Bahri, "Peşrevlerde Teslim", Musiqi Dunyasi, Volume: 4/73, 2017b, pp. 78557859.

Çakırer, H. Serdar, "Reşat Aysu'nun Nihavend Saz Semaisinin Ud Öğretimindeki Temel Davranışlara Yönelik İçerik Analizi”, İdil Journal of Art and Language, Volume: 5/20, 2016, pp. 275-292.

Değirmencioğlu, Levent and Arapgirlioğlu, Hasan, "Makamsal Viyolonsel Öğretiminde Popüler Müzik Eserlerinden Yararlanma: (Orhan Gencebay Örneği)", Journal of Erciyes University Social Sciences Institute, Volume: 2/31, 2011, pp. 199-224.

Dural, Sami, “Ali Ufkî, Kantemiroğlu ve Kevserî'nin Müzik Yazılarının Türk Müzik Geleneği Bağlamında Uzzal Peşrevi Üzerinden İncelenmesi”, Rast Musicology Journal, Volume: 2/1, 2014, pp. 147-162.

Gebeloğlu, Banu, "Mesud Cemil Bey'in Saz Eserlerinin Makamsal Analizi”, The Journal of Social Sciences Research, Volume: 13/2, 2018, pp. 305-315. 
Geboloğlu, Banu, "Tanburî Cemil Bey’in Taksîm İcralarında Hüseynî Makamı ve Arel Nazariyatına Göre Bir Karşılaştırma", Rast Musicology Journal, Volume: 3/2, 2015, pp. 994-1007.

Gürbüz, Sait and Şahin, Faruk, Sosyal Bilimlerde Araştırma Yöntemleri (Fifth edition), Seckin Publishing, Ankara 2018.

Gürel, Murat, “Nubar Tekyay’a Ait Hüzzam Keman Taksiminin Analizi”, Akademik Sanat, Volume: 1/1, 2016, pp. 94-109.

Iş1ldak, Cevahir Korhan and Geboloğlu, Banu, "Tanburî Cemil Bey'in Taksîm İcraları ve Hüseyin Sadettin Arel'in Nazariyatındaki Hüseynî Makamı Uygulamalarının Karş1laştırılması", Rast Musicology Journal, Volume: 3/2, 2015, pp. 994-1007.

İslamoğlu, Ahmet Hamdi and Ümit Alnıç̧ı, Sosyal Bilimlerde Araştırma Yöntemleri (Fifth edition), Beta Publishing, 2016.

Jasper, Melanie A. "Issues in Phenomenology for Researchers of Nursing", Journal of Advanced Nursing, Volume: 19/2, 1994, pp. 309-314.

Kahyaoğlu, Yılmaz, Kanun Sazı Öğretiminde Klasik Türk Müziği Saz Eseri Formlarının Fonksiyonlarının Incelenmesi, Unpublished Phd Diss., İnonu University, Institute of Social Sciences, Malatya 2011.

Kahyaoğlu, Yılmaz, Klasik Türk Müziğinde Saz Müziğinin Yeri ve Önemi. İnönü University Journal of Culture and Art, Volume: 1/1, 2015, pp. 57-60.

Karaca, Tolga, "15. Yüzyılda Kullanılmış Olan Bazı Makamların Analizi ve Bu Makamlardan Oluşturulan Saz Semâilerinin Türk Müziği Açısından Değerlendirilmesi”, Rast Musicology Journal, Volume: 5/2, 2017, pp. 1634-1654.

Karadeniz, M. Ekrem, Türk Musikisinin Nazariye ve Esasları (No: 238), Türkiye İş Bankası publications, Ankara 1984.

Kirk, Jerome and Marc L. Miller, Reliability and Validity in Qualitative Research (Vol.1), Sage Publications, London 1986.

Köroğlu, Gamze Nevra and Sevinç, Sema, "Klasik Kemençe Eğitiminde Kullanılan Saz Semailerinin III. Hânelerine Yönelik Hazırlanan Alıştırmaların Öğrenci Başarı Düzeylerine Etkisi”, Fine Arts (NWSAFA), Volume: 12/4, 2017, pp. 249-271.

Kula, Arda, Tanbûrî Cemîl Bey'in Saz Eserlerinin Teknik Açıdan İncelenmesi, Unpublished Master's Thesis), Afyon Kocatepe University, Institute of Social Sciences, Afyon 2018.

Küçük, Emir Murat, Hammamizâde İsmail Dede Efendi'nin Üniversitesi Nadir Eserler Kütüphanesi Hamparsum Defterlerinde Yer Alan Peşrev ve Saz Semai Formunda Eserlerinin Günümüz Nota Yazısına Çevrilmesi ve İncelenmesi, Unpublished Master’s Thesis, Halic University, Institute of Social Sciences, 2015.

Miller, Sue, "Analysis of Phenomenological Data Generated with Children as Research Participants”, Nurse Researcher, Volume: 10/4, 2003, pp. 68-82.

Özdemir, A. Tolga and N. Oya Levendoğlu Öner, "Ud İcra Geleneğinde Cinuçen Tanrıkorur Ekolünün Uzzal Taksim Üzerinden Yansımaları”, İönü University Journal of Art \& Design, Volume: 1/3, 2011, pp. 325-337.

Özgen Öztürk, Yelda and Ş. Şehvar Beşiroğlu, "Viyolonselin Türk Makam Müziğine Girişi ve Tanburi Cemil Bey”, ITÜ Journal/b Volume: 6/1, 2009, pp. 31-40.

Özgür, Ülkü and Salih Aydoğan, Gelenekten Geleceğe Makamsal Türk Müziği, Arkadaş Publishing, Ankara 2015. 
Öztuna, Yılmaz, Büyük Türk Musikisi Ansiklopedisi (Vol.2.), Kültür Bakanlığı Publications, Ankara 1990.

Rose, Pat, Jayne Beeby and David Parker, "Academic Rigour in The Lived Experience of Researchers Using Phenomenological Methods in Nursing”, Journal of Advanced Nursing, Volume: 21, 1995, pp. 1123-1129.

Saz, Leyla. Anılar: 19. Yüzyıl Saray Haremi, Cumhuriyet Kitap Kulübü, İstanbul 2000.

Soydaş, M. Emin and Ş. Şehvar Beşiroğlu, “Osmanlı Saray Müziğinde Yaylı Çalgılar”, İTÜ Journal/b, Volume: 4/1, 2007, pp. 3-12.

Taşç1, Gürkan, Türk Halk Musikisi Saz Eserlerinin Ortaöğretim Mesleki Keman Ĕ̈itiminde Kullanım Olanakları Yönüyle Incelenmesi, Unpublished Master's Thesis, Trakya University, Institute of Social Sciences, Edirne 2012.

TDK, http:॥www.tdk.gov.tr/, date of access: 28.01.2019.

Tohumcu, Ahmed and Doğrusöz, Nilgün, "Gelenekselden Popülere 20. Yüzyıl Türk Makam Müziği Üretimlerinde Değişimin İzleri”. Porte Akademik: Journal of Music \& Dance Studies, 8, 2013, pp. 22-37.

Torun, Mutlu, "Türk Müziğinin Gelişimi Üzerine Birkaç Fikir", http://www.turkishmusicportal.org/tr/makaleler/turk-muziginin-gelisimi-uzerine-birkacfikir, date of Access: 14.01.2019.

Tuncel, Emrah, Klasik Kemençe Sazında Pozisyon ve Yay Bağlarının İncelenmesi (Saz Semaisi, Peşrev ve Zeybek Formları Üzerinde Parmak Pozisyonlarl ve Yay Bağları Uygulanarak Bu Çalışmanın Klasik Kemençe Sazına Getireceği Faydaların Belirlenmesi), Unpublished Master’s Thesis, Selçuk University, Institute of Social Sciences, Konya 2008.

Ünsal Sı̆̆rı, Nitel Araştırma Yöntemleri. Beta Publishing, İstanbul 2018.

Yahya, Gülçin, Ünlü Virtüoz Yorgo Bacanos'un Ud Taksimleri:(Taksim Notalarl, Analiz ve Yorumlar) (Vol. 2980), Kültür Bakanlığı Publications, Ankara 2002.

Yalçın, Gökhan, "Nâyî Osman Dede'nin Nota Defterinden Üç Saz Eserinin Müzik Yazısı Açısından İncelenmesi”, Rast Musicology Journal, Volume: 5/1, 2017, pp. 1447-1473.

Yener, Mine, "Hamparsum Defterinden Günümüze Musi'nin Sazkar Saz Semaisi”. Rast Musicology Journal, Volume: 3/2, 2015, pp. 877-888.

Yıldırım, Ali and Hasan Şimşek, Sosyal Bilimlerde Nitel Araştırma Yöntemleri (6th edition), Seçkin Publishing, Ankara 2008.

Yıldırım, Ali and Hasan Şimşek, Sosyal Bilimlerde Nitel Araştırma Yöntemleri (10th edition). Seçkin Publishing, Ankara 2016. 